\title{
LncRna CPS1-IT1 Suppresses Cell Proliferation, Invasion and Metastasis in Colorectal Cancer
}

\author{
Wei Zhang Weitang Yuan Junmin Song Shijun Wang Xiaoming Gu \\ Department of Colorectal and Anal Surgery, The First Affiliated Hospital of Zhengzhou University, \\ Zhengzhou, Henan Province, China
}

\section{Key Words}

Long non-coding RNAs (IncRNAs) • CPS1 intronic transcript 1 (CPS1-IT1) • Colorectal carcinoma $(\mathrm{CRC}) \cdot$ Metastasis

\begin{abstract}
Background/Aims: Increasing evidence demonstrates that long non-coding RNAs (IncRNAs) regulate diverse cellular processes and cancer progression. Whether IncRNAs play any functional role in colorectal carcinoma (CRC) remains largely unknown. The aim of this study was to investigate the role of IncRNA CPS1 intronic transcript 1 (CPS1-IT1) in CRC. Methods: Expression of CPS1-IT1 was initially assessed in human CRC tissues and in a series of CRC cell lines. The correlations between CPS1-IT1 levels and survival outcomes were analyzed to elucidate the clinical significance of CPS1-IT1 in CRC. The underlying mechanisms of CPS1-IT1 in CRC were analyzed through in vitro and in vivo functional assays. Results: Expression of CPS1-IT1 was significantly decreased in CRC tissues and cell lines, and patients with low CPS1IT1 expression had poor survival outcomes. The results of in vitro assays revealed that CPS1IT1 significantly reduced cell proliferation, migration and invasion capacities and accelerated cell apoptosis, thereby suppressing epithelial-mesenchymal transition (EMT). An in vivo animal model also demonstrated the tumor-suppressive role of CPS1-IT1. Conclusion: In this study, we found that CPS1-IT1 has a tumor-suppressive role in CRC. Our data suggest that CPS1-IT1 could be used as a new prognostic biomarker and therapeutic target for CRC.
\end{abstract}

\section{Introduction}

Colorectal carcinoma (CRC) is a type of malignant neoplasm in the human digestive tract with a high morbidity rate. Its incidence and mortality are ranked third and fourth highest [1, 2], respectively, of all malignant tumors. Therefore, it is regarded as a serious threat to human health. Because of economic development and changes in people's lifestyle, the incidence of CRC is much higher than before [3]. However, in recent years, the rising morbidity rate of CRC has slowed down [4]. However, because of its subclinical manifestations and its characteristic poor 


\section{Cellular Physiology Cell Physiol Biochem 2017;44:567-580 and Biochemistry DOI: 10.1159/000485091 \begin{tabular}{l|l} 
Published 2017 The Author(s). Published by S. Karger AG, Basel \\
www.karger.com/cpb
\end{tabular} \\ Zhang et al.: The Role of Lncrna CPS1-IT1 in CRC}

prognosis, CRC has a substantial negative impact on human health. Therefore, CRC is still one of the most serious human diseases.

Research into the mechanisms underlying tumorigenesis in CRC has primarily focused on protein-coding genes. However, recent studies have revealed that non-coding RNAs (ncRNAs) are involved in regulating a wide range of physiologic functions, including cell proliferation, migration, apoptosis and tumor development [5-7]. ncRNAs are comprised of microRNAs (miRNAs), tRNAs, siRNAs, snoRNAs and long non-coding RNAs (lncRNAs) [8, 9]. miRNA have attracted a fair amount of attention over the past few decades [10,11]. A large number of studies have shown that miRNAs can induce mRNA degradation or translational inhibition and hence can mediate post-transcriptional gene silencing [6]. Specifically, approximately $30 \%$ of human genes are estimated to be regulated by miRNAs and dysregulation of them is associated with several types of cancer [12-15]. In addition, it has been shown that miRNAs can influence cell cycle progression, cell proliferation, cell invasion and apoptosis in cancer by binding with their mRNA targets [16-27].

In addition to miRNAs, much evidence has demonstrated that IncRNAs, defined as a type of RNA with a length of $>200$ nucleotides, can regulate physiological and pathological processes by interacting with DNA, RNA and protein molecules $[8,28,29]$. The lncRNAs are generally deregulated in a wide variety of diseases, including Alzheimer's disease, heart disease and cancer [30-34]. To date, a few IncRNAs have been reported to be related to the progression of human cancer $[35,36]$. Several lncRNAs have been shown to serve as prognostic and diagnostic markers, such as HOTAIR for brain, breast, and colon cancer [37-40]; MALAT-1 for liver, breast, lung, and prostate cancer [41-43]; 00C1 for colon cancer; and SChLAP1, PCA3, and PCAT-1 for prostate cancer $[44,45]$. Moreover, growing evidence has further indicated that lncRNAs functionally act as suppressors of oncogenes. For instance, IncRNA MEG3 is a recognized tumor suppressor [46]. In contrast, IncRNA MALAT1 is regarded as an oncogene which facilitates tumor metastasis and proliferation in esophageal squamous cell glioma and carcinoma $[47,48]$. The identification of crucial lncRNAs as tumor suppressors or oncogenes has given rise to the discovery of biomarkers that are valuable in the early diagnosis and treatment of cancer. IncRNA CPS1 intronic transcript 1 (lncRNA CPS1-IT1) is a tumor suppressor identified recently in the lncRNA family from HUVEC. It has primarily served as an independent predictor for disease-free survival and overall survival in lung cancer [49] and hepatocellular carcinoma [50]. Although IncRNAs have been found to be related to various cellular processes, the functions of lncRNAs in other solid tumors, including colorectal carcinoma, remain obscure.

Therefore, the objective of this study was to investigate the role of IncRNA CPS1-IT1 in colorectal cancer. Specifically, the effects of CPS1-IT1 modulation on cell metastasis, proliferation, and apoptosis are fully discussed in this study.

\section{Materials and Methods}

\section{Tissue samples}

Colorectal cancer tissues and adjacent non-cancerous normal tissues were obtained from 24 colorectal cancer patients who underwent clinical surgeries in The First Affiliated Hospital of Zhengzhou University. No patients in this study had radiotherapy or chemotherapy before the surgery. All the tumor tissues and adjacent normal tissues were snap-frozen in liquid nitrogen and stored at $-80^{\circ} \mathrm{C}$ for subsequent qRT-PCR and western blot analysis. All patients gave informed consent prior to specimen collection according to institutional guidelines. This study was approved by the Ethics Committee of Henan.

\section{Mice}

BALB/C nude mice (Laboratory Animal Center, Zhengzhou) which were 6-8-weeks-old were used in this study. The mice were bred according to the Guidelines for the Care and Use of the National Institutes of Health (NIH) at the Animal Center of Zhengzhou University. All experiments related to the animal studies were approved by the Institutional Animal Care and Use Committee (IACUC) at The First Affiliated Hospital of Zhengzhou University. 


\section{Cellular Physiology Cell Physiol Biochem 2017;44:567-580 \begin{tabular}{l|l|l|} 
DOI: 10.1159/000485091 & $\begin{array}{l}\text { C) } 2017 \text { The Author(s). Published by S. Karger AG, Basel } \\
\text { www.karger.com/cpb }\end{array}$
\end{tabular}}

Zhang et al.: The Role of Lncrna CPS1-IT1 in CRC

Cell Culture

Colorectal cancer cell lines (LoVo, SW620, SW480, LS174T, HCT116 and HT29) and normal human colorectal cells (HUVEC) were obtained from the Cell Bank of Chinese Academy of Science (Shanghai, China). The cell lines were cultured in DMEM (Gibco, USA) containing 10\% fetal bovine serum and incubated at $37^{\circ} \mathrm{C}$ in a $5 \% \mathrm{CO}_{2}$ atmosphere.

\section{Plasmid construction and cell transfection}

The pcDNA3.1 vector was purchased from Invitrogen (USA) and small interfering RNA (siRNA) was obtained from Thermo Fisher Scientific (USA). pcDNA3.1-CPS1-IT1, a plasmid containing lncRNA CPS1IT1, was constructed by Invitrogen (USA). The siRNA specifically targeting CPS1-IT1 (siRNA-CPS1-IT1) and the negative control siRNA were designed and synthesized by Thermo Fisher Scientific (USA). Colorectal cancer cell lines (LoVo and HCT116) were seeded in six-well plates at a density of $1 \times 10^{6}$ cells per well. Subsequently, the cells were transfected with pcDNA3.1-CPS1-IT1 or pcDNA3.1 (vector1) and CPS1-IT1specific siRNAs or the negative control siRNA (vector2) by using Lipofectamine ${ }^{\mathrm{TM}} 2000$ (Invitrogen, USA) according to the manufacturer's instructions. After transfection, cells were incubated for $24 \mathrm{~h}$ and then used for further assays.

\section{Quantitative real-time PCR ( $q R T$-PCR) assay}

The expression of CPS1-IT1 was detected by qRT-PCR assay according to the methods described previously [51]. Total RNA was extracted from tissues and cultured cells with TRIzol reagent (Thermo Fisher Scientific, USA). The RNA samples were subjected to reverse transcription by the GoScript Reverse Transcription System (Qiagen GmbH, Germany). The sequences of the PCR primers used were as follows: CPS1-IT1, forward 5'-CAC AGA TGA TCC ACG GCG TT-3' and reverse 5'-GCG TGC ATC AAT GAC ACT TCA-3'; and GAPDH, forward 5'-CGG AGT CAA CGG ATT TGG TCG TAT TGG-3' and reverse 5'-GCT CCT GGA AGA TGG TGA TGG GAT TTC C-3' [52]. RT-PCR analysis was performed with the ABI 7900 Detection System (Applied Biosystems, USA). The relative expression of RNA was calculated by the $2^{-\Delta \Delta C t}$ method. GAPDH was used as an internal reference.

\section{Colony formation assay}

Twenty-four hours after transfection, both LoVo and HCT116 cells were trypsinized, counted and seeded into 12-well plates at 100 cells per well in triplicate. The medium was replaced every 3 days during the colony growth. After incubation in DMEM for 12 days, the colonies were fixed with methanol and stained with crystal violet (Sigma, USA). The colonies were considered as survivors and counted only when they contained more than 50 cells. Colony formation rate was calculated with the following formula: colony formation rate $=($ number of colonies $/$ number of seeded cells $) \times 100 \%$.

\section{Cell cycle assay}

For the cell cycle analysis, the cells were trypsinized with $0.25 \%$ trypsin, washed twice with PBS, and then fixed in $70 \%$ ethanol at $4^{\circ} \mathrm{C}$ overnight. Subsequently, the cells were stained with $10 \mu \mathrm{l}$ of propidium iodide (PI, Sigma, USA) that contained $10 \mu \mathrm{g}$ RNase A (Sigma, USA) for $30 \mathrm{~min}$ at $4^{\circ} \mathrm{C}$ in the dark. Samples were analyzed using a FACScan flow cytometer (Becton-Dickinson, USA).

\section{Annexin-V FITC/PI double staining assay}

Annexin-V FITC/PI analysis was performed to determine the apoptosis of cells. The LoVo and HCT116 cells were collected by low speed centrifugation (centrifuged at $2000 \mathrm{r} / \mathrm{min}$ for $3 \mathrm{~min}$ ) and washed twice with ice-cold PBS. Then, $300 \mu \mathrm{l}$ binding buffer was added to the cells. Afterward, the cells were incubated with $5 \mu \mathrm{l} \mathrm{PI}$ and $5 \mu \mathrm{l}$ annexin V-FITC at $4^{\circ} \mathrm{C}$ for 5-15 min in the dark. Finally, cell apoptosis was detected within 60 min by flow cytometry (Cytomics ${ }^{\mathrm{TM}}$ FC 500, USA).

\section{Wound-healing assay}

Cell migration activity was analyzed using a wound-healing assay. Treated LoVo and HCT116 cells were plated onto 6-well plates at a density of $5 \times 10^{5}$ cells per well and cultured to $100 \%$ confluence. Afterward, cells were scraped with a pipette tip (tips range in volume from 1 to $200 \mu \mathrm{l}$ ) in a cross pattern in the center of each well, washed with PBS, and immediately given fresh low-serum medium. Forty-eight hours after 


\section{Cellular Physiology Cell Physiol Biochem 2017;44:567-580 \begin{tabular}{l|l|l} 
and Biochemistry Published onlIne: Novermber 17, 2017 & $\begin{array}{l}\text { (c) } 2017 \text { The Author(s). Published by S. Karger AG, Basel } \\
\text { www.karger.com/cpb }\end{array}$ \\
\hline
\end{tabular} \\ Zhang et al:: The Role of Lncrna CPS1-IT1 in CRC}

growth, the migration distances of the cells were observed and photographed under a Nikon microscope (Minato) at a magnification of $200 \times$ for each group.

\section{Transwell assay}

Cell invasion was determined by Transwell assays. The membrane of the chamber was coated with 30 $\mathrm{mg} / \mathrm{cm}^{2}$ Matrigel (BD Biosciences, USA) for $1 \mathrm{~h}$ at $37^{\circ} \mathrm{C}$ to form a matrix barrier. The lower chambers were filled with $600 \mu \mathrm{l}$ of medium (DMEM supplemented with $10 \%$ FBS). The cells were suspended in DMEM to a concentration of $1 \times 10^{5}$ cells per well and were loaded into each upper well in a $200 \mu$ l total volume. After the chambers cultured in $5 \% \mathrm{CO}_{2}$ at $37^{\circ} \mathrm{C}$ for 24 hours, cells were fixed with methanol for 10 min and stained with crystal violet for 10 min. Subsequently, cells were washed with PBS. Counts were obtained from five random fields at $200 \times$ magnification.

\section{Western blotting assay}

The expression of E-cadherin, Z0-1, N-cadherin and vimentin was detected by Western blot analysis. The transfected cells or murine tumor tissues were lysed in $200 \mu \mathrm{l}$ RIPA lysis buffer containing $50 \mathrm{mM}$ Tris-HCl (pH 7.4), $150 \mathrm{mM} \mathrm{NaCl}, 0.1 \%$ SDS, 1\% sodium deoxycholate, 1 mM EDTA, 1\% Triton X-100 and protease inhibitors. Then, the proteins were separated with $10 \%$ SDS-PAGE prior to being transferred onto nitrocellulose (NC) membranes (Amersham Bioscience, U.K.). Following blocking with skim milk, the membranes were incubated with primary antibodies against E-cadherin, ZO-1, N-cadherin, vimentin and $\beta$-actin overnight. All these antibodies were purchased from Sigma (USA). Chemiluminescent signals were visualized using ECL detection reagents (Amersham Biosciences, Sweden). $\beta$-actin was used as a control. Each protein sample was examined in triplicate.

\section{Lentiviral infection and in vivo metastasis assays}

For the CPS1-IT1 shRNAs, self-complementary oligonucleotides carrying siRNAs against human CPS1IT1 were designed (Sunbio, China). This product was cloned into the pMagic 4.1 lentiviral vector (pMagicCPS1-IT1-shRNA) (Clontech, USA) at AgeI and EcoRI sites, and the pMagic 4.1 vector was used as the negative control (Lenti-vector2). For generation of recombinant CPS1-IT1 for overexpression, the human CPS1-IT1 sequence was amplified by PCR from a cDNA template. This product was cloned into the pLVXEGFP-3FLAG lentiviral vector (Clontech, USA) at EcoRI sites. Thus, the pLVX-CPS1-IT1 vector was created and the pLVX-EGFP-3FLAG vector (Lenti-vector1) was used as the negative control. Subsequently, LoVo cells were infected with the viral suspensions. LoVo cell lines $\left(1 \times 10^{6}\right)$ stably expressing CPS1-IT1 or CPS1-IT1 shRNAs were injected into the tail veins of nude mice. Tumor volume was measured every three days using digital calipers and recorded. For the in vivo metastasis assays, mice were sacrificed at 45 days. The tumor weight was measured. Lung and liver metastases were examined using H\&E staining with a microscope.

\section{Statistical analysis}

All data were analyzed with SPSS 17.0 (SPSS Inc, USA) and expressed as the mean \pm S.D. Student's t-test was used to analyze differences between two groups. One-way ANOVA was used to perform the multisample analysis. Survival analysis was estimated by Kaplan-Meier method. All statistical tests were twosided, and a P value less than 0.05 was considered significant.

\section{Results}

CPS1-IT1 expression is decreased in CRC

To interpret the biological functionality of lncRNA CPS1-IT1 in colorectal carcinoma, we first detected CPS1-IT1 expression in 24 paired colorectal cancer tissues and adjacent noncancerous normal tissues using qRT-PCR. The results revealed that the relative expression of CPS1-IT1 was notably decreased in colorectal tumor tissues compared to their adjacent non-cancerous counterparts ( $\mathrm{p}<0.001)$, indicating a potential role of CPS1-IT1 as a tumor suppressor (Fig. 1A). 
A

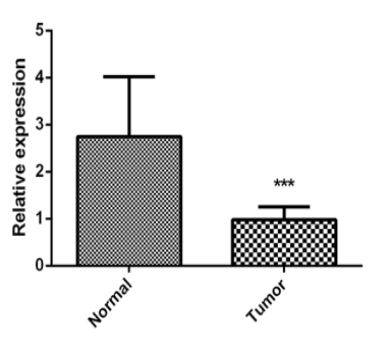

B

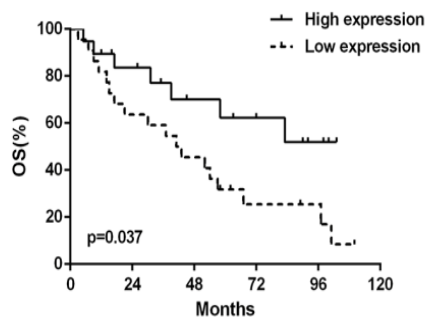

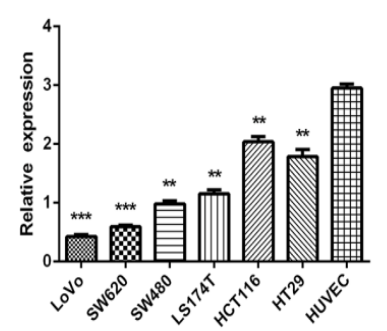

Fig. 1. Relative expression of CPS1-IT1 in human colorectal carcinoma and adjacent non-cancerous normal tissues as well as in different colorectal carcinoma cell lines of varying metastatic potential. A. Relative expression of CPS1-IT1 in 24 colorectal carcinoma tissues compared with adjacent non-cancerous normal tissues. CPS1-IT1 levels were detected with quantitative RT-PCR. B. Kaplan-Meier analysis of overall survival according to CPS1-IT1 expression levels was performed. High CPS1-IT1 expression ( $\geq$ median value of expression) and low CPS1-IT1 expression (< median value of expression) were used to define groups. C. LoVo and SW620 were highly metastatic cell lines, SW480 and LS174T were moderately metastatic cell lines, and HCT116 and HT29 were weakly metastatic cell lines. HUVEC were used as a control. ${ }^{* * *} \mathrm{p}<0.001$.

Decreased CPS1-IT1 expression is associated with poor prognosis of colorectal cancer

To assess the clinical significance of CPS1-IT1, we further studied the relationship between the expression of CPS1-IT1 and survival outcome in 24 colorectal cancer patients. The patients were subclassified into high CPS1-IT1 expression ( $\geq$ median value of expression) and low CPS1-IT1 expression (< median value of expression) groups. The acquired data were subsequently subjected to Kaplan-Meier survival analysis. The results demonstrated that among the colorectal cancer cohort, lower CPS1-IT1 expression was associated with poor overall survival (Fig. 1B).

\section{CPS1-IT1 expression in colorectal carcinoma cell lines}

To determine the influence of CPS1-IT1 in colorectal carcinoma, we detected the expression of CPS1-IT1 in different colorectal carcinoma cell lines with varying metastatic potentials. As shown in Fig. 1C, all six colorectal carcinoma cell lines exhibited considerably lower expression of CPS1-IT1 when compared with HUVECs, and the relative expression levels of CPS1-IT1 were the lowest in the highly metastatic LoVo cell line and the highest in the weakly metastatic HCT116 cell line. Therefore, these two cell lines were chosen for use in the subsequent assays. These data show that IncRNA CPS1-IT1 was down-regulated in human colorectal carcinoma in vitro.

The influence of CPS1-IT1 on cell proliferation, apoptosis and cell cycle in human CRC

To further investigate the role of lncRNA CPS1-IT1 in colorectal carcinoma, a CPS1-IT1 expression plasmid was constructed and transfected into LoVo and HCT116 cells. In addition, CPS1-IT1-specific siRNAs were synthesized and transfected into LoVo and HCT116 cells. The results showed that the expression of CPS1-IT1 in the CPS1-IT1 expression plasmidtransfected group was significantly increased compared with the vector1 group in both cell lines $(p<0.01)$ and the relative transcript levels of CPS1-IT1 were reduced in the CPS1-IT1specific siRNA group compared with the negative control siRNA group (vector2) $(p<0.01)$ (Fig. 2A, 2B). The results mentioned above indicated that the CPS1-IT1 expression plasmid and the CPS1-IT1 siRNA were successful in modulating CPSI-IT1 expression. Subsequently, a colony formation assay was conducted using LoVo and HCT116 cells. It was shown that the colony number in LoVo and HCT116 cells was decreased upon transfection with the CPS1-IT1 expression plasmid, while the colony number in LoVo and HCT116 cells was enlarged when cells were transfected with CPS1-IT1-specific siRNA (Fig. 2C, 2D). Afterward, we investigated the potential role of CPS1-IT1 in cell apoptosis. The results showed that the apoptotic rates 


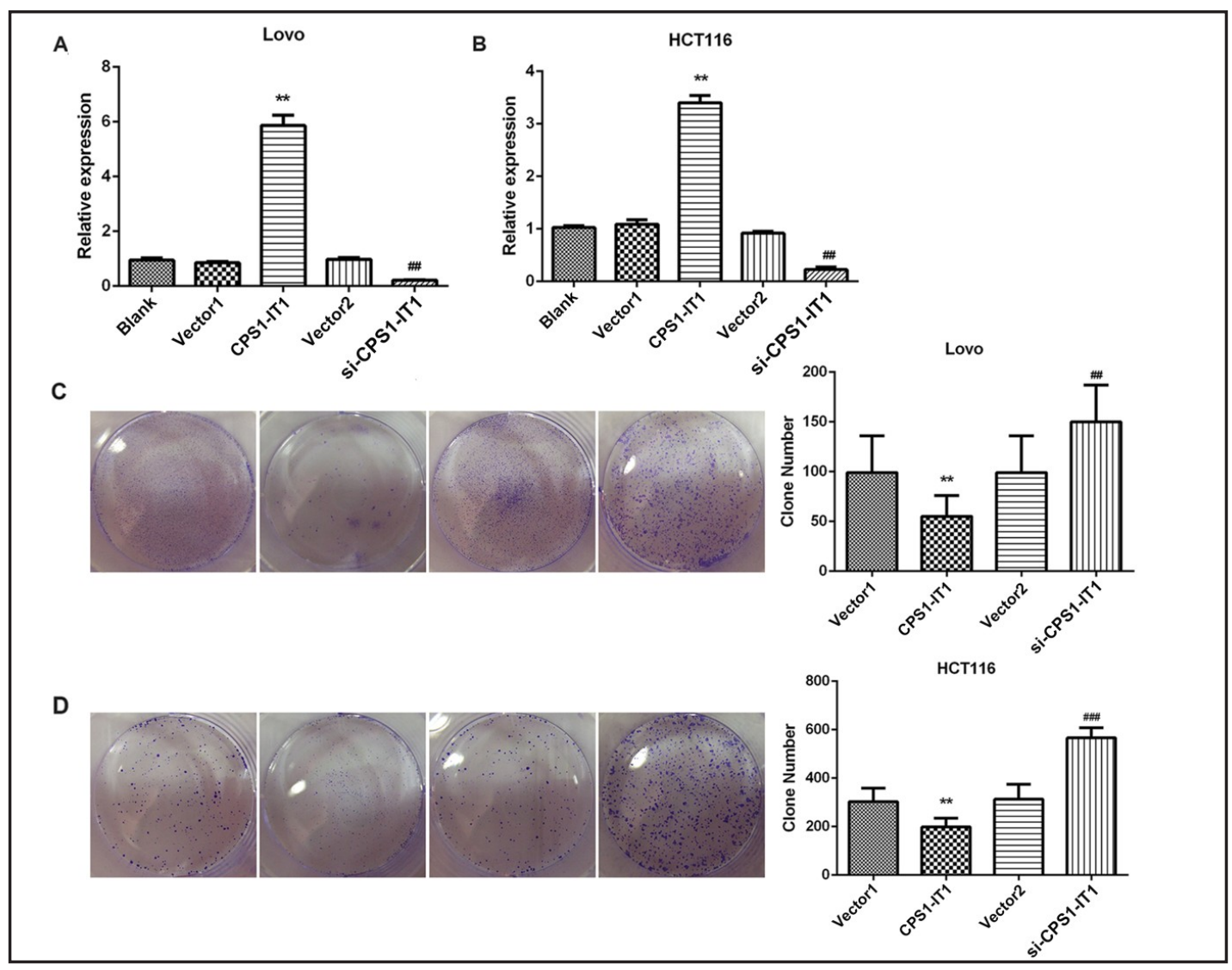

Fig. 2. Overexpression of CPS1-IT1 inhibited cell proliferation in colorectal carcinoma cell lines. A, B. A CPS1-IT1 expression plasmid was constructed on the pcDNA3.1 vector backbone and transfected into LoVo and HCT116 cells. CPS1-IT1-specific siRNA was synthesized and transfected into LoVo and HCT116 cells. RT-PCR analysis was used to determine the relative expression of CPS1-IT1 in both cell lines. C, D. Colony formation ability was analyzed in cells at 12 days after transfection with the CPS1-IT1-overexpressing plasmid or CPS1-IT1-siRNA. CPS1-IT1 overexpression significantly inhibited the colony formation ability of LoVo and HCT116 cells. However, CPS1-IT1-siRNA significantly elevated the colony forming ability of LoVo and HCT116 cells. Blank: colorectal carcinoma cells without any treatment. ${ }^{* *} \mathrm{p}<0.01$ versus vector1 group. \#\# $\mathrm{p}<0.01$ versus vector2 group.

were increased upon treatment with the CPS1-IT1 expression plasmid, while the apoptotic rates were decreased when transfected with CPS1-IT1 siRNA (Fig. 3A, 3B). In addition, flow cytometric analysis was carried out to explore the effect of lncRNA CPS1-IT1 on cell cycle progression. The results revealed that overexpression of CPS1-IT1 in LoVo and HCT116 cells increased the fraction of cells at G0/G1 phase and reduced the fraction of cells at S and G2/M phases (Fig. 3C, 3D), while the results showed an opposite trend in LoVo and HCT116 cells with CPS1-IT1 suppression.

\section{The effect of CPS1-IT1 on cell migration and invasion}

Moreover, we determined cell migration and invasion capacity using wound-healing assays and transwell assays. The migration capacity of CPS1-IT1 overexpressing cells was decreased in comparison with the vector1 group, whereas suppression of CPS1-IT1 enhanced the cell migration capacity (Fig. 4A, 4B). The cell invasion assays presented similar results, showing that the invasion capacity of both CPS1-IT1-overexpressing LoVo and HCT116 cell lines reduced by approximately $44 \%$ and $69 \%$, respectively, compared with the vector1 group (Fig. 4C, 4D). Taken together, these results showed that CPS1-IT1 inhibited cancer cell migration and invasion capacities.

\section{KARGER}


Fig. 3. $\ln -$ cRNA CPS1IT1 regulated colorectal cancer cell a p optos is and cell cycle in vitro. A, B. Cell apoptosis was detected using a n n e x i n - V FITC/PI double staining in the LoVo and HCT116 cells. C, D. The expression of CPS1IT1 in LoVo and HCT116 cells at $\mathrm{GO} /$ G1 phase and at $\mathrm{S}$ and G2/M phases. $\quad$ p $<0.05$, ${ }^{* * *} \mathrm{p}<0.001$ versus vector1 group. ${ }^{\#} \mathrm{p}<0.05$, ${ }^{\# \#} \mathrm{p}<0.01$ versus vector2 group.

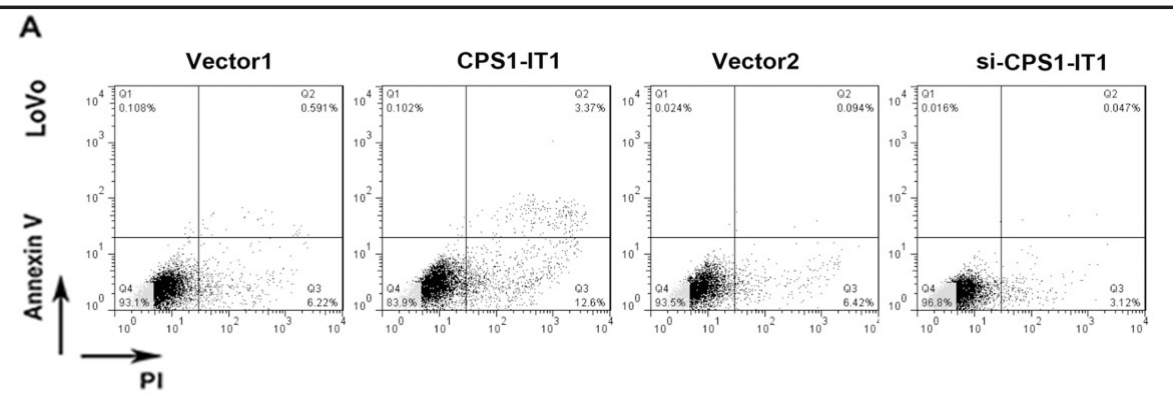

B
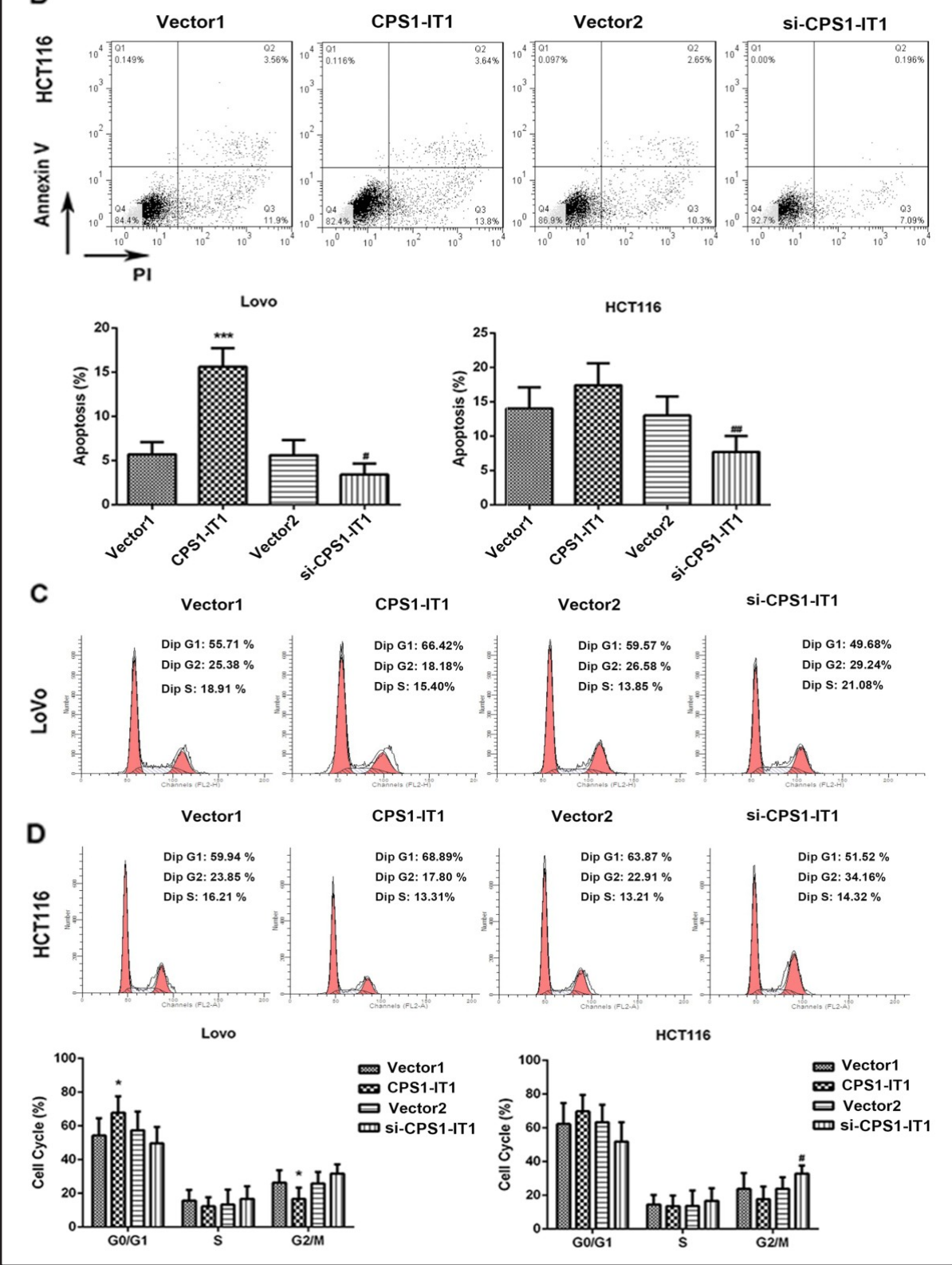

\section{CPS1-IT1 inhibits epithelial-mesenchymal transition}

Occurrence of epithelial-mesenchymal transition (EMT) during tumorigenesis may increase the invasiveness and motility of cancer cells, and malignant transformation may be related to signaling pathways that promote EMT [26]. To further assessed associations 


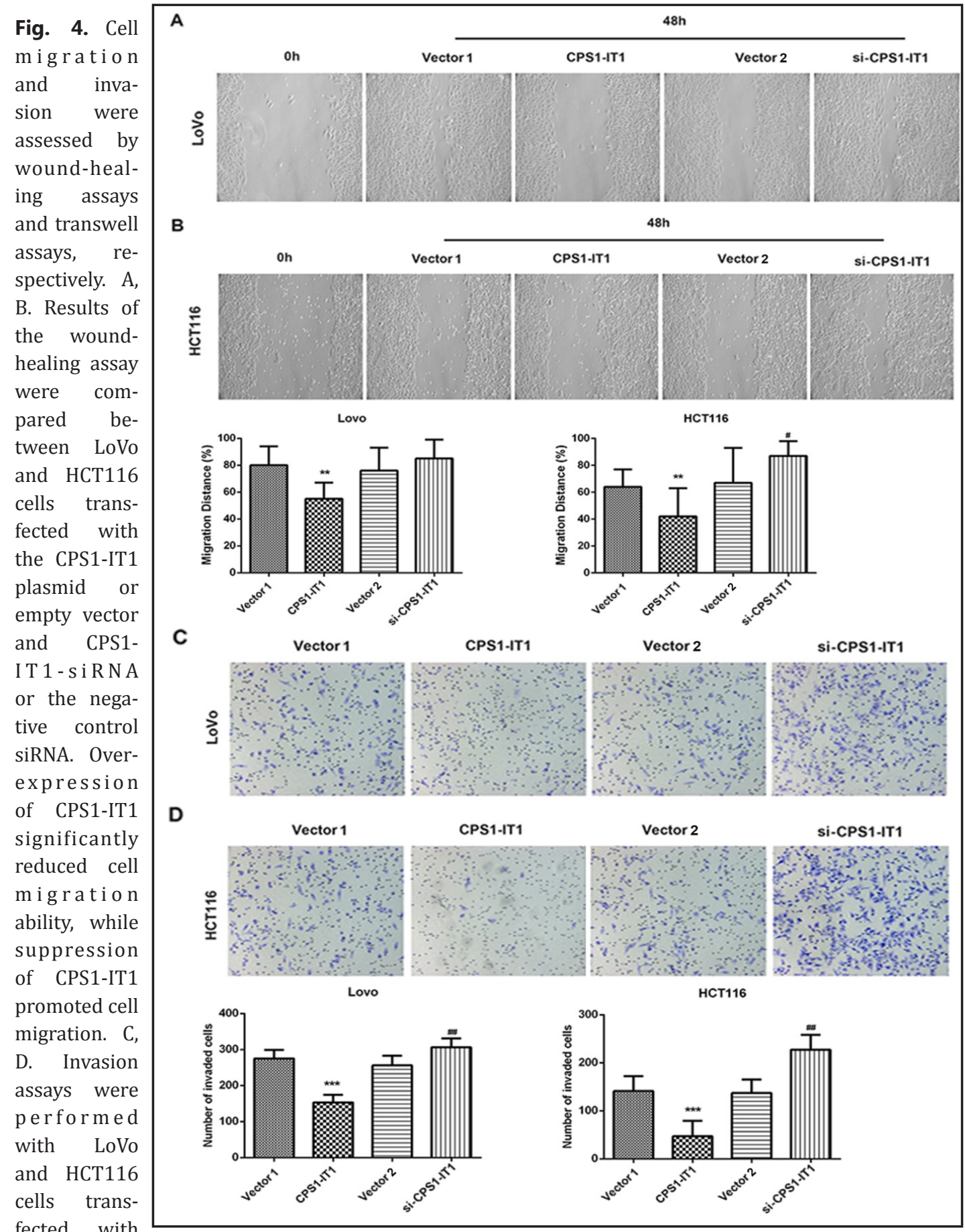

fected with

either the

CPS1-IT1-overexpressing plasmid, empty vector, CPS1-IT1-siRNA or the negative control siRNA, and the results were compared between treatment and control groups. Overexpression of CPS1-IT1 significantly reduced cell invasion ability, whereas suppression of CPS1-IT1 promoted cell invasion. ${ }^{* *} \mathrm{p}<0.01,{ }^{* * *} \mathrm{p}<0.001$ versus vector1 group. ${ }^{\#} \mathrm{p}<0.05,{ }^{\# \#} \mathrm{p}<0.01$ versus vector 2 group.

between EMT and CPS1-IT1 in colorectal cancer, we analyzed the expression of EMTassociated proteins, including E-cadherin, ZO-1, N-cadherin and vimentin in LoVo and HCT116 cell lines. Expression of vimentin and N-cadherin were decreased in CPS1-IT1overexpressing cells, while the levels of E-cadherin and ZO-1 were increased (Fig. 5A, 5B). KARGER 
Fig. 5. Western blotting analysis of EMT-associated proteins, including E-cadherin, ZO-1, N-cadherin and vimentin, after transfection with either CPS1-IT1-overexpressing plasmid, empty vector, CPS1-IT1-siRNA or the negative control siRNA. $\beta$-actin served as the internal control. A. EMT-associated proteins were detected in LoVo cells. Overexpression of CPS1-IT1 inhibited epithelialmesenchymal transition, whereas suppression of CPS1-IT1 promoted epithelial-mesenchymal transition. B. Western blot analyses revealed the levels of EMTassociated proteins in HCT116 cells. Overexpression of CPS1-IT1 inhibits epithelial-mesenchymal transition, while suppression of CPS1-IT1 promoted epithelialmesenchymal transition.
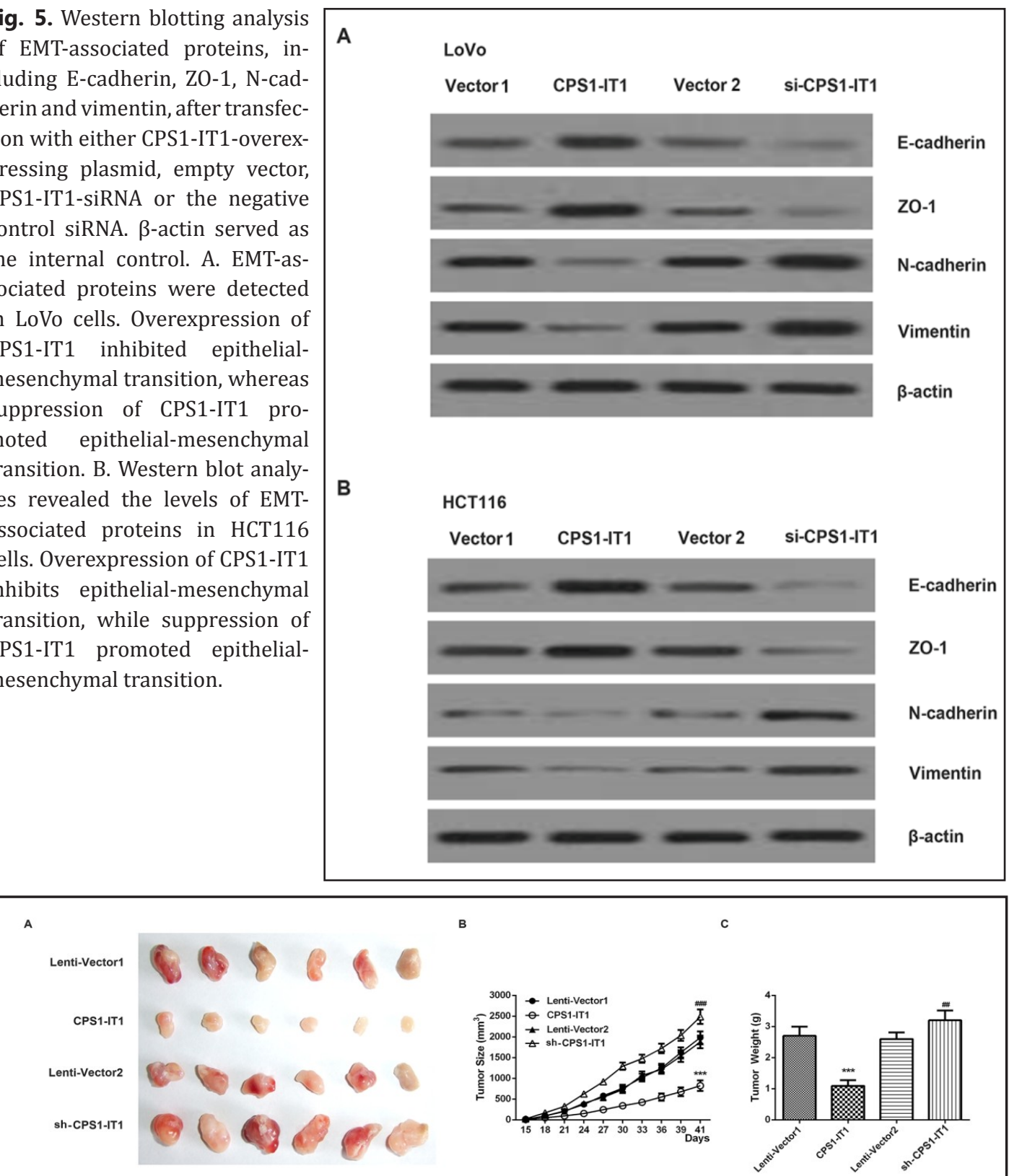

B

c
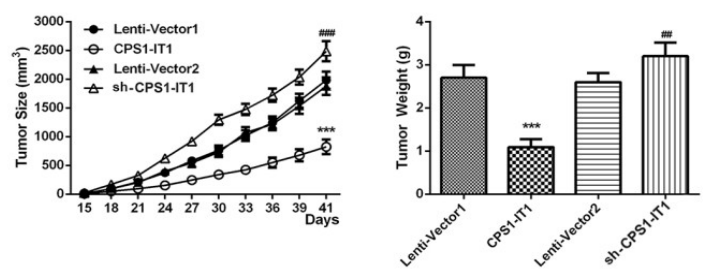

Fig. 6. CPS1-IT1 reduces growth of CRC cells in vivo. A, B. LoVo cells stably transfected with CPS1-IT1 or CPS1-IT1-shRNA, were injected into nude mice. Tumor volumes were calculated every 3 days after injection. C. Mice were sacrificed after 45 days and the tumor weight was measured ${ }^{* * *} \mathrm{p}<0.001$ versus Lenti-vector1 group. ${ }^{\# \#} \mathrm{p}<0.01,{ }^{\# \#} \mathrm{p}<0.001$ versus Lenti-vector 2 group.

However, the EMT-related proteins showed a reverse trend in CPS1-IT1-suppressed cells. These results demonstrated that CPS1-IT1 plays a tumor suppressive role by preventing EMT.

\section{CPS1-IT1 suppresses tumor growth and metastasis in vivo}

To further confirm the tumor suppressor role of CPS1-IT1 in colorectal cancer, in vivo xenografts were generated via tail vein injection. In accordance with previous results, the size and weight of tumors from CPS1-IT1-overexpressing xenografts was remarkably reduced compared with the lenti-vector 1 group at 41 days after injection, whereas the growth of KARGER 


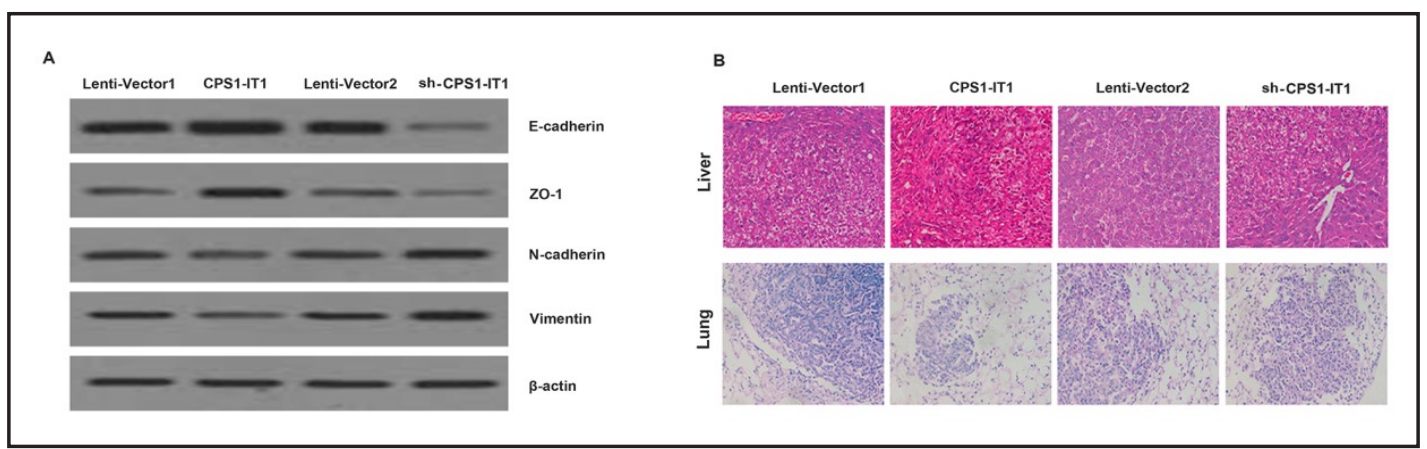

Fig. 7. CPS1-IT1 reduces EMT and metastasis of CRC cells in vivo. A. Western blots revealed that CPS1-IT1 reduced the expression of EMT-associated proteins in CRC cells in vivo. B. Representative images of lung and liver metastases as illustrated by H\&E staining of tissues from nude mice at 45 days after tail vein injection with LoVo cells stably transfected with CPS1-IT1 overexpression vector or CPS1-IT1-shRNA. CPS1IT1 significantly reduced tumor metastasis

tumors from CPS1-IT1-siRNA xenografts was increased (Fig. 6A-6C). Western blots were performed to demonstrate the regulation of EMT by CPS1-IT1. Like the results of the in vitro cell assay, expression of EMT-promoting proteins, such as N-cadherin and vimentin, was decreased in CPS1-IT1-overexpressing tumors, while expression of E-cadherin was increased. However, the expression of EMT-related proteins showed a reverse trend in CPS1IT1-suppressed cells. An inhibitory effect of CPS1-IT1 on the lung and liver metastasis of colorectal carcinoma was also observed in both LoVo and HCT116 cells (Fig. 7A, 7B).

\section{Discussion}

CRC is one of the most common malignancies worldwide and is the fourth leading cause of cancer-related death [2]. Under most circumstances, symptoms of cancer are detected at an advanced stage, leading to poor prognosis. Consequently, the exploration of new diagnostic and therapeutic biological targets for CRC is especially important. In addition to microRNAs, emerging discoveries suggest that lncRNAs are also important factors in cell biology. It has been suggested that IncRNA dysregulation is associated with a variety of human diseases, including cancer [53-55]. However, the function of lncRNAs in CRC remains unknown. In the present study, we analyzed CPS1-IT1, a novel lncRNA, and confirmed its tumor-suppressive effect in human CRC cells.

We found that the expression of CPS1-IT1 was remarkably reduced in human CRC specimens, and low CPS1-IT1 expression in human CRC was related to poor prognostic outcome. This finding was in accordance with the previous study which recognized CPS1IT1 as a tumor suppressor in hepatocellular carcinoma [49] and lung cancer [50]. Moreover, both in vitro assays and an in vivo animal models verified that CPS1-IT1 suppresses tumor growth by reducing CRC cell proliferation, migration and invasion capacities as well as by promoting cell apoptosis, thereby suppressing EMT. Hence, these findings suggest that CPS1IT1 might be a tumor suppressor in human CRC that could serve as a prognostic biomarker for the disease.

Tumor metastases are the primary causes of cancer-related death, and EMT is recognized to increase the motility and invasiveness of cancer cells $[56,57]$. EMT is a process whereby differentiated epithelial cells undergo a transition to a mesenchymal phenotype and become motile and invasive, properties that are closely associated with metastasis [58]. In our study, we found that overexpression of CPS1-IT1 remarkably reduced cell migration and invasion capacities. In addition, expression of EMT-associated proteins, including E-cadherin, ZO-1, $\mathrm{N}$-cadherin and vimentin, was reduced in CPS1-IT1-overexpressing cells. These findings suggested that CPS1-IT1 might reduce human CRC metastasis by suppressing EMT. This 


\section{Cellular Physiology Cell Physiol Biochem 2017;44:567-580 \begin{tabular}{ll|l} 
and Biochemistry & $\begin{array}{l}\text { DOI.1159/000485091 } \\
\text { Published online: Novermber 17, } 2017\end{array}$ & $\begin{array}{l}\text { O } 2017 \text { The Author(s). Published by S. Karger AG, Basel } \\
\text { www.karger.com/cpb }\end{array}$ \\
\cline { 2 - 3 }
\end{tabular} \\ Zhang et al.: The Role of Lncrna CPS1-IT1 in CRC}

discovery was supported by prognostic analysis. Poorer overall survival was related to the decrease of CPS1-IT1 expression in CRC patients. Furthermore, the level of apoptosis increased with overexpression of CPS1-IT1, and it could be concluded that IncRNA CPS1-IT1 induced cell apoptosis. In addition, the induction of apoptotic activity is a good way to inhibit the proliferation of cancer cells [59]. All these data demonstrate that lncRNA CPS1-IT1 might be a tumor suppressor in CRC and could serve as a molecular biomarker for the diagnosis of CRC.

lncRNA dysregulation causes a range of biological dysfunction and provides a cellular growth advantage, leading to progressive and uncontrolled tumor growth [60]. However, the molecular mechanisms by which lncRNAs regulate cancer cells are diverse.

lncRNAs can serve as guides for proteins to reach their targets, as regulatory signals for transcription, as hubs to localize transcription factors, as a framework to bridge different proteins, as 'sponges' to sequester microRNAs, and as molecules that can allosterically alter the functions of proteins $[61,62]$. For instance, CPS1-IT1 was found to interact with HSP90 in human hepatocellular carcinoma. CPS1-IT1 is required to activate and stabilize numerous proteins involved in essential cellular processes [63]. In addition, CPS1-IT1 was also found to suppress the growth of hepatocellular carcinoma by inhibiting epithelial-mesenchymal transition and regulating HIF- $1 \alpha$ activity [49]. The mechanism of the inhibitory effect of IncRNA CPS1-IT1 on CRC growth needs to be further studied.

\section{Conclusion}

Our data show that IncRNA CPS1-IT1 exerts a tumor-suppressive effect on human CRC cells. Specifically, CPS1-IT1 suppresses tumor growth by reducing cell proliferation, migration and invasion capacities as well as by promoting cell apoptosis, thereby suppressing EMT. Our study provides new insights into the function of lncRNAs in the development of human CRC and demonstrates that CPS1-IT1 represents a potential prognostic biomarker and therapeutic target for human CRC.

\section{Acknowledgements}

This work did not receive any funding.

\section{Disclosure Statement}

The authors declare no conflict of interest.

\section{References}

$\rightarrow 1$ Jemal A: Global Cancer Statistics. CA Cancer J Clin 2011;61:69-9.

-2 Colorectal cancer in Iran: Epidemiology and morphology trends. Excli J 2016;15:738-744.

-3 JJ S-B: Mortality trends and risk of dying from colorectal cancer in the seven socioeconomic regions of Mexico, 2000-2012. Rev Gastroenterol Mex 2017;82:217-225.

4 Douaiher J, Ravipati A, Grams B, Chowdhury S, Alatise 0, Are C: Colorectal cancer\&mdash;global burden, trends, and geographical variations. J Surg Oncol 2017;115:619-630.

5 Cech T, Steitz J: The Noncoding RNA Revolution-Trashing Old Rules to Forge New Ones. Cell 2014;157:77.

6 Ling H, Fabbri M, Calin GA: MicroRNAs and other non-coding RNAs as targets for anticancer drug development. Nat Rev Drug Discov 2013;12:847-865. 


\section{Cellular Physiology Cell Physiol Biochem 2017;44:567-580 \begin{tabular}{l|l|l} 
and Biochemistry 10.1159/000485091 & $\begin{array}{l}\text { C } 2017 \text { The Author(s). Published by S. Karger AG, Basel } \\
\text { www.karger.com/cpb }\end{array}$
\end{tabular}}

Zhang et al.: The Role of Lncrna CPS1-IT1 in CRC

7 Wang TH, Lin YS, Chen Y, Yeh CT, Huang Y, Hsieh TH, Shieh TM, Hsueh C, Chen TC: Long non-coding RNA AOC4P suppresses hepatocellular carcinoma metastasis by enhancing vimentin degradation and inhibiting epithelial-mesenchymal transition. Oncotarget 2011;6:23342-23357.

-8 Eddy SR: Non-coding RNA genes and the modern RNA world. Nat Rev Genet 2001;2:919-929.

9 Mattick JS, Makunin IV: Non-coding RNA. Hum Mol Genet 2006;15:R17-29.

10 Xie T, Huang M, Wang Y, Wang L, Chen C, Chu X: MicroRNAs as Regulators, Biomarkers and Therapeutic Targets in the Drug Resistance of Colorectal Cancer. Cell Physiol Biochem 2016;40:62-76.

11 Han R, Sun Q Wu J, Zheng P, Zhao G: Sodium Butyrate Upregulates miR-203 Expression to Exert AntiProliferation Effect on Colorectal Cancer Cells. Cell Physiol Biochem 2016;39:1919-1929.

12 Jiang J, Gusev Y, Aderca I, Mettler TA, Nagorney DM, Brackett DJ, Roberts LR, Schmittgen TD: Association of MicroRNA expression in hepatocellular carcinomas with hepatitis infection, cirrhosis, and patient survival. Clin Cancer Res 2008;14:419.

-13 Köberle V, Kronenberger B, Pleli T, Trojan J, Imelmann E, Peveling-Oberhag J, Welker MW, Elhendawy M, Zeuzem S, Piiper A: Serum microRNA-1 and microRNA-122 are prognostic markers in patients with hepatocellular carcinoma. Eur J Cancer 2013;49:3442.

14 Park JK, Kogure T, Nuovo GJ, Jiang J, He L, Kim JH, Phelps MA, Papenfuss TL, Croce CM, Patel T: miR-221 silencing blocks hepatocellular carcinoma and promotes survival. Cancer Res 2011;71:7608.

15 Giordano S, Columbano A: MicroRNAs: New tools for diagnosis, prognosis, and therapy in hepatocellular carcinoma? Hepatology 2013;57:840-847.

16 Hayashita Y, Osada H, Tatematsu Y, Yamada H, Yanagisawa K, Tomida S, Yatabe Y, Kawahara K, Sekido Y, Takahashi T: A polycistronic microRNA cluster, miR-17-92, is overexpressed in human lung cancers and enhances cell proliferation. Cancer Res 2005;65:9628-9632.

17 Li T, Li D, Sha J, Sun P, Huang Y: MicroRNA-21 directly targets MARCKS and promotes apoptosis resistance and invasion in prostate cancer cells. Biochem Biophys Res Commun 2009;383:280.

18 Ma L, Teruya-Feldstein J, Weinberg RA: Tumour invasion and metastasis initiated by microRNA-10b in breast cancer. Nature 2007;449:682-688.

19 Petrocca F, Visone R, Onelli MR, Shah MH, Nicoloso MS, De MI, Iliopoulos D, Pilozzi E, Liu CG, Negrini M: E2F1-regulated microRNAs impair TGFbeta-dependent cell-cycle arrest and apoptosis in gastric cancer. Cancer Cells 2008;13:272-286.

20 Volinia S, Calin GA, Liu CG, Ambs S, Cimmino A, Petrocca F, Visone R, Iorio M, Roldo C, Ferracin M: A microRNA expression signature of human solid tumors defines cancer gene targets. Proc Natl Acad Sci U S A 2006;103:2257-2261.

21 Liu X, Xie T, Mao X, Xue L, Chu X, Chen L: MicroRNA-149 Increases the Sensitivity of Colorectal Cancer Cells to 5-Fluorouracil by Targeting Forkhead Box Transcription Factor FOXM1. Cell Physiol Biochem 2016;39:617.

-22 Zhang W, Zou C, Pan L, Xu Y, Qi W, Ma G, Hou Y, Jiang P: MicroRNA-140-5p Inhibits the Progression of Colorectal Cancer by Targeting VEGFA. Cell Physiol Biochem 2015;37:1123.

-23 Fang Y, Sun B, Xiang J, Chen Z: MiR-301a Promotes Colorectal Cancer Cell Growth and Invasion by Directly Targeting SOCS6. Cell Physiol Biochem 2015;35:227-236.

24 Xu K, Liu X, Mao X, Xue L, Wang R, Chen L, Chu X: MicroRNA-149 Suppresses Colorectal Cancer Cell Migration and Invasion by Directly Targeting Forkhead Box Transcription Factor FOXM1. Cell Physiol Biochem 2015;35:499.

25 Wei W, Yang Y, Cai J, Cui K, Li R, Wang H, Shang X, Wei D: MiR-30a-5p Suppresses Tumor Metastasis of Human Colorectal Cancer by Targeting ITGB3. Cell Physiol Biochem 2016;39:1165.

26 Li H, Zhang H, Chen Y, Liu X, Qian J: MiR-423-3p Enhances Cell Growth Through Inhibition of p21Cip1/Waf1 in Colorectal Cancer. Cell Physiol Biochem 2014;37:1044-1054.

-27 Zhou L, Xu Z, Ren X, Chen K, Xin S: MicroRNA-124 (MiR-124) Inhibits Cell Proliferation, Metastasis and Invasion in Colorectal Cancer by Downregulating Rho-Associated Protein Kinase 1(ROCK1). Cell Physiol Biochem 2016;38:1785-1795.

28 Suresh V, Liu L, Adjeroh D, Zhou X: Revealing protein-lncRNA interaction. Nucleic Acids Res 2015;43:13701379.

29 Lukas J, Altmeyer M: A lncRNA to repair DNA. Embo Rep 2015;16:1413.

30 Batista P, Chang H: Long Noncoding RNAs: Cellular Address Codes in Development and Disease. Cell 2013;152:1298-1307. 


\section{Cellular Physiology Cell Physiol Biochem 2017;44:567-580 \begin{tabular}{l|l|l} 
and Biochemistry 10.1159/000485091 & $\begin{array}{l}\text { C } 2017 \text { The Author(s). Published by S. Karger AG, Basel } \\
\text { www.karger.com/cpb }\end{array}$ \\
\hline
\end{tabular} \\ Zhang et al.: The Role of Lncrna CPS1-IT1 in CRC}

-31 Faghihi MA, Modarresi F, Khalil AM, Wood DE, Sahagan BG, Morgan TE, Finch CE, Rd SLG, Kenny PJ, Wahlestedt C: Expression of a noncoding RNA is elevated in Alzheimer's disease and drives rapid feedforward regulation of beta-secretase. Nat Med 2008;14:723-730.

-32 Liu Y, Pan S, Liu L, Zhai X, Liu J, Wen J, Zhang Y, Chen J, Shen H, Hu Z: A Genetic Variant in Long Non-Coding RNA HULC Contributes to Risk of HBV-Related Hepatocellular Carcinoma in a Chinese Population. Plos One 2012;7:e35145.

-33 Schonrock N, Harvey RP, Mattick JS: Long noncoding RNAs in cardiac development and pathophysiology. Circ Res 2012;111:1349-1362.

-34 Tan L, Yu JT, Hu N, Tan L: Non-coding RNAs in Alzheimer's disease. Mol Neurobiol 2013;47:382-393.

35 Fang XY, Pan HF, Leng RX, Ye DQ: Long noncoding RNAs: Novel insights into gastric cancer. Cancer Lett 2015;356:357.

-36 Yong H, Xiao-Ming M, Cheng H, Bao-Ming W, Lei Z, Xiong-Wen L, Jun L: Long noncoding RNAs: Novel insights into hepatocelluar carcinoma. Cancer Lett 2014;344:20-27.

-37 Cai B, Song XQ Cai JP, Zhang S: HOTAIR: a cancer-related long non-coding RNA. Neoplasma 2014;61:379391.

38 Gupta RA, Shah N, Wang KC, Kim J, Horlings HM, Wong DJ, Tsai MC, Hung T, Argani P, Rinn JL: Long noncoding RNA HOTAIR reprograms chromatin state to promote cancer metastasis. Nature 2010;464:1071.

-39 Kogo R, Shimamura T, Mimori K, Kawahara K, Imoto S, Sudo T, Tanaka F, Shibata K, Suzuki A, Komune S, Miyano S, Mori M: Long Noncoding RNA HOTAIR Regulates Polycomb-Dependent Chromatin Modification and Is Associated with Poor Prognosis in Colorectal Cancers. Cancer Res 2011;71:6320-6326.

40 Zhang JX, Han L, Bao ZS, Wang YY, Chen LY, Yan W, Yu SZ, Pu PY, Liu N, You YP: HOTAIR, a cell cycleassociated long noncoding RNA and a strong predictor of survival, is preferentially expressed in classical and mesenchymal glioma. Neuro Oncol 2013;15:1595-1603.

-41 Ji P, Diederichs S, Wang W, Böing S, Metzger R, Schneider PM, Tidow N, Brandt B, Buerger H, Bulk E: MALAT-1, a novel noncoding RNA, and thymosin beta4 predict metastasis and survival in early-stage nonsmall cell lung cancer. Oncogene 2003;22:6087-6097.

-42 Lai MC, Yang Z, Zhou L, Zhu QQ Xie HY, Zhang F, Wu LM, Chen LM, Zheng SS: Long non-coding RNA MALAT-1 overexpression predicts tumor recurrence of hepatocellular carcinoma after liver transplantation. Med Oncol 2012;29:1810.

43 Xu C, Yang M, Tian J, Wang X, Li Z: MALAT-1: a long non-coding RNA and its important 3' end functional motif in colorectal cancer metastasis. Int J Oncol 2011;39:169-175.

- 44 Ge X, Chen Y, Liao X, Liu D, Li F, Ruan H, Jia W: Overexpression of long noncoding RNA PCAT-1 is a novel biomarker of poor prognosis in patients with colorectal cancer. Med Oncol 2013;30:588.

45 Sahu A, Asangani IA, Cao Q Patel L: The long noncoding RNA SChLAP1 promotes aggressive prostate cancer and antagonizes the SWI/SNF complex. Nat Genet 2013;45:1392-1398.

-46 Zhang X, Zhou Y, Mehta KR, Danila DC, Scolavino S, Johnson SR, Klibanski A: A pituitary-derived MEG3 isoform functions as a growth suppressor in tumor cells. J Clin Endocrinol Metab 2003;88:5119.

47 Hu L, Wu Y, Tan D, Meng H, Wang K, Bai Y, Yang K: Up-regulation of long noncoding RNA MALAT1 contributes to proliferation and metastasis in esophageal squamous cell carcinoma. J Exp Clin Cancer Res 2015;34:7.

48 Ma KX, Wang HJ, Li XR, Li T, Su G, Yang P, Wu JW: Long noncoding RNA MALAT1 associates with the malignant status and poor prognosis in glioma. Tumor Biol 2015;36:3355-3359.

-49 Wang TH, Yu CC, Lin YS, Chen TC, Yeh CT, Liang KH, Shieh TM, Chen CY, Hsueh C: Long noncoding RNA CPS1-IT1 suppresses the metastasis of hepatocellular carcinoma by regulating HIF-1 $\alpha$ activity and inhibiting epithelial-mesenchymal transition. Oncotarget 2016;7:43588.

50 Zhao X, Liu M, Zhang J, Zhang R, Zhang Q Tan X: Long noncoding RNA CPS1-IT1 suppresses cell proliferation and metastasis in human lung cancer. Oncol Res 2017;5:373-380.

51 Tang J, Cai H, Lin L, Xie P, Zhong W, Tang M: Increased expression of CD24 is associated with tumor progression and prognosis in patients suffering osteosarcoma. Clin Transl Oncol 2013;15:541-547.

52 Ma SL, Li AJ, Hu ZY, Shang FS, Wu MC: Co-expression of the carbamoyl-phosphate synthase 1 gene and its long non-coding RNA correlates with poor prognosis of patients with intrahepatic cholangiocarcinoma. Mol Med Rep 2015;12:7915-7926.

-53 Malek E, Jagannathan S, Driscoll JJ: Correlation of long non-coding RNA expression with metastasis, drug resistance and clinical outcome in cancer. Oncotarget 2014;5:8027. 


\section{Cellular Physiology Cell Physiol Biochem 2017;44:567-580 \begin{tabular}{ll|l} 
and Biochemistry 10.1159/000485091 & $\begin{array}{l}\text { O 2017 The Author(s). Published by S. Karger AG, Basel } \\
\text { www.karger.com/cpb }\end{array}$ \\
\cline { 1 - 3 }
\end{tabular} \\ Zhang et al.: The Role of Lncrna CPS1-IT1 in CRC}

54 Wang F, Ying HQ, He BS, Pan YQ, Deng QW, Sun HL, Chen J, Liu X, Wang SK: Upregulated lncRNA-UCA1 contributes to progression of hepatocellular carcinoma through inhibition of miR-216b and activation of FGFR1/ERK signaling pathway. Oncotarget 2015;6:7899.

55 Zhang K, Sun X, Zhou X, Han L, Chen L, Shi Z, Zhang A, Ye M, Wang Q, Liu C: Long non-coding RNA HOTAIR promotes glioblastoma cell cycle progression in an EZH2 dependent manner. Oncotarget 2015;6:537-546.

56 Chen X, Lingala S, Khoobyari S, Nolta J, Zern MA, Wu J: Epithelial mesenchymal transition and hedgehog signaling activation are associated with chemoresistance and invasion of hepatoma subpopulations. J Hepatol 2011;55:838-845.

57 Park MY, Kim KR, Park HS, Park BH, Choi HN, Jang KY, Chung MJ, Kang MJ, Lee DG, Moon WS: Expression of the serum response factor in hepatocellular carcinoma: implications for epithelial-mesenchymal transition. Int J Oncol 2007;31:1309-1315.

58 Willis BC, Borok Z: TGF-beta-induced EMT: mechanisms and implications for fibrotic lung disease. Am J Physiol Lung Cell Mol Physiol 2007;293:525-534.

-59 Luscan A, Shackleford G, Masliah-Planchon J, Laurendeau I, Ortonne N, Varin J, Lallemand F, Leroy K, Dumaine V, Hivelin M: The activation of the WNT signaling pathway is a Hallmark in neurofibromatosis type 1 tumorigenesis. Clin Cancer Res 2014;20:358.

60 Prensner JR, Chinnaiyan AM: The emergence of lncRNAs in cancer biology. Cancer Discov 2011;1:391-407.

61 Geisler S, Coller J: RNA in unexpected places: long non-coding RNA functions in diverse cellular contexts. Nat Rev Mol Cell Biol 2013;14:699.

62 Liang WC, Fu WM, Wong CW, Wang Y, Wang WM, Hu GX, Zhang L, Xiao LJ, Wan CC, Zhang JF: The lncRNA H19 promotes epithelial to mesenchymal transition by functioning as miRNA sponges in colorectal cancer. Oncotarget 2015;6:22513-22525.

63 Li J, Soroka J, Buchner J: The Hsp90 chaperone machinery: Conformational dynamics and regulation by cochaperones. Biochim Biophys Acta 2012;1823:624. 